\title{
Retraction: Corrigendum: Akt2 Regulates the Differentiation and Function of NKT17 Cells via Fox0-1-ICOS Axis
}

\section{OPEN ACCESS}

Approved by:

Chen Dong,

Tsinghua University, China

${ }^{*}$ Correspondence:

Frontiers Editorial Office

editorial.office@frontiersin.org

Specialty section: This article was submitted to T Cell Biology,

a section of the journal

Frontiers in Immunology

Received: 28 May 2021

Accepted: 28 May 2021

Published: 14 June 2021

Citation:

Frontiers Editorial Office (2021) Retraction: Corrigendum: Akt2

Regulates the Differentiation and Function of NKT17 Cells via

FoxO-1-ICOS Axis.

Front. Immunol. 12:716458 doi: 10.3389/fimmu.2021.716458
Frontiers Editorial Office*

\author{
A Retraction of the Correction Article \\ Corrigendum: Akt2 Regulates the Differentiation and Function of NKT17 Cells via FoxO-1- \\ ICOS Axis \\ by Niu L, Xuan X, Wang J, Li L, Yang D, Jing Y, Westerberg LS and Liu C (2020). Front. Immunol. \\ 11:589346. doi: 10.3389/fimmu.2020.589346
}

The journal and Chief Editors retract the 30 September 2020 article cited above.

Following the publication of the article, image duplication concerns were identified in the published article, specifically in Figure 3J. The authors were unable to provide a satisfactory explanation for this occurrence despite issuing a Correction article. As a result, the data and conclusions of the article have been deemed unreliable. The Correction article is therefore being retracted.

The authors concur with the retraction and sincerely regret any inconvenience this may have caused to the reviewers, editors and readers of Frontiers in Immunology.

Copyright (C) 2021 Frontiers Editorial Office. This is an open-access article distributed under the terms of the Creative Commons Attribution License (CC BY). The use, distribution or reproduction in other forums is permitted, provided the original author(s) and the copyright owner(s) are credited and that the original publication in this journal is cited, in accordance with accepted academic practice. No use, distribution or reproduction is permitted which does not comply with these terms. 